\title{
P73. Functional characterisation of HBV-specific $T$ cell receptors for redirection of $T$ cells against HBV infected hepatocytes
}

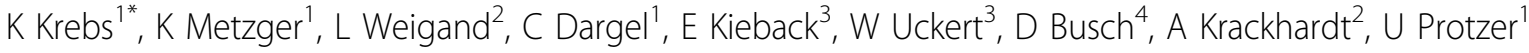 \\ From 1st Immunotherapy of Cancer Conference (ITOC1) \\ Munich, Germany. 12-14 March 2014
}

Chronic HBV infection, which is accompanied by a weak and oligoclonal $\mathrm{T}$ cell response, is the most common cause of hepatocellular carcinoma (HCC). Current antiviral therapies do not eliminate the virus, but $\mathrm{T}$ cell therapy will very likely do so. From PBMCs of two HLA-A2 ${ }^{+}$acutely infected patients and a donor who cleared HBV infection we have established several HBVspecific monoclonal $\mathrm{T}$ cell lines. Thereof we isolated 11 different $\mathrm{T}$ cell receptors (TCR) that are specific for the HBV S-protein derived peptides S20 (FLLTRILTI) and S172 (WLSLLVPFV) or for the C18 core-peptide (FLPSDFFPSV). The aim of this study was a functional comparison of our set of HBV-specific TCRs in order to identify TCRs with optimal recognition of HBV peptides presented on HLA-A2.

By murinization and codon-optimisation of gene sequences of TCR a and b chains, fused by a P2A element for polycystronic expression, TCR expression after retroviral transduction was increased 2 -fold to $60 \%$ of PBMCs expressing an HBV-specific TCR.

PBMCs transduced with the 11 optimised HBV-specific TCRs were compared in killing assays using peptidepulsed T2 cells, LCLs and HBV-replicating HepG2.2.15 cells as targets. $\mathrm{CD}^{+} \mathrm{T}$ cells transduced with the corespecific TCRs killed target cells loaded with $0.01 \mathrm{nM}$ of peptide. Cells specific for the S20 and S172 peptide were less sensitive with a specific lysis as low as $0.1 \mathrm{nM}$. Expression of most of the HLA-A2 restricted HBV-specific TCRs in $\mathrm{CD}^{+} \mathrm{T}$ cells also led to specific cytotoxicity, which was 10 -fold reduced in sensitivity compared to $\mathrm{CD} 8^{+} \mathrm{T}$ cells and independent of CD8 co-receptor binding. Notably, our HBV-specific TCRs recognised peptide presented on various different HLA-A2 subtypes.

CD8 ${ }^{+} \mathrm{T}$ cells transduced with HBV-specific TCRs were also able to recognise endogenously processed peptides and specifically kill HBV-replicating hepatoma cells and strongly reduce cccDNA levels in HBV-infected HepaRG cells.

In addition, intracellular cytokine staining after stimulation showed that the TCR-transduced $\mathrm{CD}^{+} \mathrm{T}$ cells were polyfunctional, secreting INF- $\gamma$, TNF- $\alpha$ and IL-2, whereas $\mathrm{CD}^{+} \mathrm{T}$ cells produced mainly TNF-a and/or IL-2.

We will further analyse our HBV-specific TCRs in HBV/HLA-A2 transgenic mice in order to identify the TCR that confers best antiviral activity. Our HBV-specific TCRs may be used for elucidating specific anti-HBV mechanisms exerted by $\mathrm{T}$ cells, and most importantly, for adoptive $\mathrm{T}$ cell therapy of chronic hepatitis $\mathrm{B}$ and HBV-induced HCC.

\section{Authors' details}

'TU Muenchen / Helmholtz Zentrum Muenchen, Institute of Virology, Muenchen, Germany. ${ }^{2}$ Klinikum rechts der Isar, III. Medizinische Klinik, Muenchen, Germany. ${ }^{3}$ Max-Delbrück Center for Molecular Medicine, Berlin, Germany. ${ }^{4}$ TU Muenchen, Institute for Medical Microbiology Immunology and Hygiene, Muenchen, Germany.

Published: 12 March 2014

doi:10.1186/2051-1426-2-S2-P47

Cite this article as: Krebs et al:: P73. Functional characterisation of HBVspecific T cell receptors for redirection of T cells against HBV infected hepatocytes. Journal for ImmunoTherapy of Cancer 2014 2(Suppl 2):P47.

${ }^{1}$ TU Muenchen / Helmholtz Zentrum Muenchen, Institute of Virology,

Muenchen, Germany

Full list of author information is available at the end of the article

(c) 2014 Krebs et al; licensee BioMed Central Ltd. This is an Open Access article distributed under the terms of the Creative Commons Attribution License (http://creativecommons.org/licenses/by/2.0), which permits unrestricted use, distribution, and reproduction in any medium, provided the original work is properly cited. The Creative Commons Public Domain Dedication waiver (http:// creativecommons.org/publicdomain/zero/1.0/) applies to the data made available in this article, unless otherwise stated. 